\title{
KONGEN, KRIGEN OG RINGEN
}

En litterær undersøgelse af J.R.R. Tolkiens Ringenes Herre set i lyset af Georges Dumézils teori om den trefunktionelle struktur i indoeuropæisk mytologi ${ }^{1}$

\section{Nanna Kinch}

ENGLISH ABSTRACT: This article provides a reading of the English author J.R.R. Tolkien's The Lord of the Rings in light of the French scholar of religion, Georges Dumézil, and his theory of the trifunctional structure of Indo-European mythology.

The article argues that the nine companions of The Fellowship of the Ring constitute a trifunctional structure in which the first function is represented by Gandalf (the magical side of power) and Aragorn (the political side of power), the second function (war and battle) is represented by Legolas, Gimli and Boromir, and the third function, that of fertility, is represented by the four hobbits. The trifunctional structure is recognizable not only in the characters and their cultural backgrounds, but also in the different ways these characters and cultures are confronted with Sauron, and trifunctionality shapes the narrative in its three main themes: the king, the war and the Ring.

DANSK RESUME: Den engelske forfatter J.R.R. Tolkiens Ringenes Herre (RH) kan betragtes som et stykke moderne mytologi, der udviser samme trefunktionelle struktur, som den franske religionsforsker Georges Dumézil har identificeret $i$ indoeuropæeisk mytologi og religion.

Trefunktionaliteten kommer til udtryk i Ringens Broderskab, hvor førstefunktionen reprcesenteres af Gandalf (magtens magiske side) og Aragorn (magtens politiske side), andenfunktionen (krig og kamp) repræsenteres af Legolas, Gimli og Boromir, og tredjefunktionen (frugtbarheden) reprcesenteres af de fire hobbitter. Den trefunktionelle struktur optrceder ikke blot blandt disse personer og deres kulturelle baggrunde, men også i de handlingstråde, personerne følger, og i måden, hvorpå de konfronteres med Saurons ondskab. Trefunktionaliteten former således fortcellingen i dens tre grundtemaer: kongen, krigen og Ringen.

KEYWORDS: J.R.R. Tolkien; Georges Dumézil; trifunctionality.

\section{Indledning}

Hvordan giver det mening at beskæftige sig med den engelske forfatter J.R.R. Tolkien fra et religionsvidenskabeligt synspunkt? Argumenterne er mange, og sagen kan anskues fra flere sider. Man kan for det første betragte dyrkelsen af Tolkiens univers

\footnotetext{
${ }^{1}$ Artiklen er en bearbejdelse af mit speciale med samme titel indleveret ved Aarhus Universitets Afdeling for Religionsvidenskab 19. januar 2005. For kommentarer takker jeg netredaktør, Ph.d., Morten Thomsen Højsgaard.
} 
som et eksempel på den refortrylning af kulturen, der ifølge Gilhus og Mikaelsson er en moderne manifestation af religiøsiteten (Gilhus \& Mikaelsson 1998). Eller man kan knytte an ved Stig Hjarvards nye undersøgelse af, hvordan bøger og film for moderne danskere udgør væsentlige kilder til at beskæftige sig med åndelige og moralske spørgsmål. Hjarvards undersøgelse fremhæver specielt Ringenes Herre $(R H)^{2}$ som en af de væsentlige, store fortællinger om det godes kamp mod det onde (Hjarvard 2005, 179f). En tredje mulighed er at tage udgangspunkt i, at Tolkien selv oprindeligt betragtede sit forfatterskab som et forsøg på at skabe eller rekonstruere en mytologi for England. Han ville afdække de legender, der var gået tabt, og som nu kun er kendt i brudstykker (Chance Nitzsche 1979, 1f) På samme måde som Brødrene Grimm havde gjort i Tyskland, Elias Lönnrot havde gjort i Finland og Grundtvig havde gjort i Danmark, ville Tolkien rekonstruere helheden i Englands mytologi, og han forstod selv sit forfatterskab som en mytologisk asterisk, ${ }^{3}$ snarere end som digtning (Shippey 2001, xv). Tolkiens forfatterskab har da også en række træk til fælles med mytologi. Hans univers er distanceret, men ikke løsrevet fra vores verden, og handlingen foregår i mytens tid og rum, "in illo tempore" (Tjalve 1972, 180f). Tolkien rammer en naturlig, folkelig trang til fantastiske fortællinger (Shippey 2001, xxv) og specielt $R H$ er i sit indhold en historie, der rummer sit samfunds og sin tids dybeste følelser (Shippey 1992, 184). Som Robinson Crusoe er en myte om kapitalismen, og Faust er en myte om videnskabsmanden, kan $R H$ betragtes som en myte imod modløsheden ('discouragement', s. 184). Endelig bærer $R H$ det mytologiske træk, at fortællingen forsøger at mediere mellem tilsyneladende modsætninger: hedensk og kristent, eskapisme og realisme, sejr og nederlag (Shippey 2001, xxxii).

Denne artikel føjer sig til rækken af argumenter, der kan anføres for at betragte $R H$ som mytologi. Jeg vil redegøre for, hvordan Georges Dumézils teori om den trefunktionelle struktur både kan belyse nye lag af strukturer og betydninger hos Tolkien og samtidig kan forbinde hans forfatterskab med dets baggrund i den indoeuropæiske mytologi-som Tolkien i kraft af sit professionelle arbejde ${ }^{4}$ var særdeles velbevandret $\mathrm{i}$. Dumézils teori om, hvordan en treleddet struktur af suverænitet (den verdslige og religiøse magt), kamp (krig og fysisk styrke) og frugtbarhed (rigdom, overflod, fred) kaldet den trefunktionelle struktur (Dumézil 1958, 19) - optræder i indoeuropæisk religion og mytologi, har kun i begrænset omfang været sat i forbindelse med Tolkiens værk. Artiklen indleder med en kort skitse af disse studier. Herefter følger en redegørelse for den grundlæggende trefunktionelle struktur i RH, og en undersøgelse af de videre perspektiver af denne trefunktionalitet i relation til personer, kulturer, handling og tematik. Til slut skitseres nogle forskelle på trefunktionaliteten hos Tolkien og i

\footnotetext{
${ }^{2}$ I øvrigt citeres Tolkiens værker med følgende forkortelser: The Lord of the Rings (LR), LR Bind III: The Return of the King (RK), Silmarillion (Sil), The Letters of J.R.R. Tolkien (Let), Unfinished Tales of Númenor and Middle-earth (UT), The Return of the Shadow. The History of Middle-earth. Volume 6 (RS).

${ }^{3}$ Dvs. det tegn $(*)$, der bruges inden for filologien til at markere et ord, der ikke er observeret, men hvis eksistens kan rekonstrueres.

${ }^{4}$ Tolkien var professor i angelsaksisk filologi i Oxford.
} 
indoeuropæisk mytologi, og der trækkes linjer til denne undersøgelses videre perspektiver for læsningen af henholdsvis Dumézil og Tolkien.

\section{Studier af Tolkien i relation til Dumézil}

Blandt mange og vidt forskellige indfaldsvinkler til Tolkiens forfatterskab fokuserer de fleste på hans inspiration og baggrund samt på temaer, budskaber og ideologi i forfatterskabet. Meget få har interesseret sig for at foretage strukturelle analyser, og den engelsksprogede forskning - som udgør langt hovedparten - er i denne sammenhæng stort set ubekendt med Dumézil. ${ }^{5}$ Forsøgene på at læse Tolkien i lyset af Dumézil skal derimod findes inden for den begrænsede fransksprogede Tolkienforskning.

Eksempelvis har Jean Chausse (2003) argumenteret for, hvordan Silmarillions ${ }^{6}$ fortælling om krigeren Túrin har mange lighedspunkter med Dumézils beskrivelse af krigeren $\mathrm{i}$ indoeuropæisk mytologi, og at Túrin gennemspiller temaet om krigerens tre synder. ${ }^{7}$ Laurent Alibert påpeger, hvordan $R H$ illustrerer den forestilling, der er udbredt i bl.a. den indoeuropæiske verden, om en nær sammenhæng mellem landets frugtbarhed og den rette konge, og hvordan Aragorn er et typisk eksempel på et forhold, som også Dumézil har iagttaget, nemlig at suverænitetsfunktionen ofte optræder som en syntese af alle tre funktioner (Alibert 2002, 19f).

Det eneste samlede forsøg på en gennemarbejdet analyse af, hvilke trefunktionelle strukturer, der overordnet gør sig gældende i Tolkiens værk, foreligger i et upubliceret såkaldt memoire af Frédérique Munier fra 1987. Memoirets styrke og svaghed er, at Munier tager udgangspunkt i Silmarillion og ubetinget viderefører de tre funktioners karakteristika herfra på Tolkiens værk som helhed. Hermed overser hun, at elverkulturen i $R H$ spiller en anden rolle end i Silmarillion, og at trefunktionaliteten i $R H$ får tilføjet et nyt element i kraft af hobbitterne.

Munier redegør for, hvordan de tre elverslægter: Vanyar, Noldor og Telerier i Silmarillions første del udgør en trefunktionel struktur. Den elverslægt, der kommer til at dominere historien, er Noldorne, der repræsenterer andenfunktionen. De er voldelige, opfarende og ureflekterede og udfører store heltebedrifter, men deres virketrang kommer også til udtryk i både håndværksmæssige færdigheder og intellektuel nysgerrighed (Munier 1987a, 44f). Ifølge Munier udfolder trefunktionaliteten sig på et nyt niveau i Noldornes videre historie, hvor tre slægter igen repræsenterer hver sin funktion. I lighed med den grundliggende, trefunktionelle struktur afviger også denne trefunktionalitet på visse punkter fra de klassiske, indoeuropæiske funktionskarakteristika. Særligt er en visdom og indfølingsevne føjet til tredjefunktionens felt, der dermed synes

\footnotetext{
${ }^{5}$ Nogle få undtagelser er Sandra Miesel (1973, 56; 2005) samt muligvis Stephen Yandell (1995).

${ }^{6}$ Silmarillion er en samling af Tolkiens tidlige digtning, som han vedblev at revidere hele sit liv. Under arbejdet med $R H$ kom Silmarillions fortællinger til at danne den mytologiske baggrund for Midgård, den verden, hvori $R H$ foregår.

${ }^{7}$ Et tema, som Dumézil har beskrevet i Aspects de la fonction guerrière (Dumézil 1956), Mythe et épopée II (Dumézil 1982) og Heur et malheurs du guerrier (Dumézil 1985).
} 
at låne visse træk fra førstefunktionen (s. 60f) - en pointe, jeg senere vil vende tilbage til.

Til slut vender Munier sig mod $R H$ og argumenterer for det lidt søgte synspunkt, at tredjefunktionen i denne fortælling skulle være splittet mellem på den ene side frugtbarhed og trivsel, repræsenteret ved hobbitterne, og på den anden side skønhed og nydelse, repræsenteret ved elverne (s. 96). Hun redegør endvidere for, hvordan både Gondors og Rohans kongehuse og de fire hobbitter indbyrdes er struktureret efter det trefunktionelle skema (s. 140f).

\section{Den trefunktionelle grundstruktur i Ringenes Herre}

Identifikationen af den trefunktionelle struktur i $R H$ tager udgangspunkt i Ringens Broderskab, det bærende omdrejningspunkt $\mathrm{i}$ fortællingen. ${ }^{8}$ Rådsforsamlingen $\mathrm{i}$ Kløvedal, hvor broderskabets deltagere udvælges, er både geografisk, kulturelt og narrativt et centrum, og som helhed repræsenterer broderskabets ni deltagere Midgårds frie folk, og modsvarer i antal de ni ringånder. Som jeg vil redegøre for i det efterfølgende, består Ringens Broderskab af en delt førstefunktion (Gandalf og Aragorn), en andenfunktion (Boromir, Legolas og Gimli) og en tredjefunktion (Frodo, Sam, Merry og Pippin). Funktionerne repræsenteres i første omgang ved de nævnte personer, i anden omgang ved disses racemæssige og kulturhistoriske baggrund og i tredje omgang ved de handlingstråde, som disse personer involveres $i$.

Troldmanden Gandalfs relation til den magisk-religiøse side af førstefunktionen er åbenlys. Hans lederskab er båret af intelligens, visdom og viden (fx $L R, 266,300)$ og en synskhed $(L R, 845)$, som også kommer til udtryk i hans elvernavn, Olórin, der betyder klarsyn ("clear vision", UT, 396). Både han og hans korrumperede spejlbillede, troldmanden Saruman, tilhører de fem Istari, der er udsendt fra Vesten $(L R, 1059)$, fra guderne. Men hvor Saruman er en stationær figur, der ruger på sin viden, fordi den for ham ikke er et mål i sig selv, men derimod et middel til magt (fx $L R, 252$ ), er Gandalfs viden et resultat af hans omrejsen, årvågenhed og spontane nysgerrig $(U T, 349)$, og hans rolle er udpræget kommunikativ. Gandalf repræsenterer den åbne viden, hvor kærligheden, nysgerrigheden og respekten for det højere ærinde er drivkraften i videbegæret, mens Saruman repræsenterer den lukkede viden, hvor stolthed og magtbegær er drivkraften, og bevidstheden om det højere ærinde er gået tabt. De personificerer således to forskellige aspekter af førstefunktionens magisk-religiøse side; nemlig dem, der fremkommer gennem henholdsvis den rette og den forkerte funktionsudøvelse, en parallelitet, som også Marjorie Burns (Burns 2000, 229) og Tolkien selv har bemærket (Let, 180).

Den landsforviste tronarving Aragorn har som Gandalfs lærling og arvtager $(L R$, 485f) del i hans viden (fx $L R, 225,375)$, og også han har synske evner ( $L R, 830 \mathrm{f})$.

\footnotetext{
${ }^{8}$ Et resumé af handlingen i de to første bind findes i begyndelsen af tredje bind af $R H(R K 2001$, ixf). Et rids af hele historien om Midgård findes i mit speciale (Kinch 2005, 5f), der kan fås ved henvendelse til Det Teologiske Fakultet ved Aarhus Universitet.
} 
Imidlertid er de forskellige på det punkt, at hvor Gandalf repræsenterer det overordnede, indirekte og delvist guddommelige lederskab, repræsenterer Aragorn den direkte, dennesidige og politisk engagerede ledelse. Da Gandalf som sin sidste opgave i Midgård kroner Aragorn til konge $(L R, 946)$, markeres overgangen til affortryllelsens og menneskenes tidsalder således ved, at det magisk-religiøse aspekt af førstefunktionen viger til fordel for det politiske aspekt.

Aragorns kongelighed udfolder sig i fortællingen gennem en række af initiationer ( $\mathrm{fx}$ $L R, 366,384,423)$, hvor hans diplomatiske evner, hans viljestyrke og ikke mindst hans evne til at træffe valg afprøves. Aragorn er dog ikke udelukkende karakteriseret gennem de evner, der knytter sig til førstefunktionen. I lige så høj grad er han et eksempel på, at førstefunktionens politisk-juridiske side fremstår som en syntese af funktionerne (Alibert 2002, 20). Han har både krigsførende og helbredende evner (LR, 846f. 937f), og hans kærlighedsforhold til Arwen er flettet sammen med historien om hans vej til kongetronen ( $L R, 365.1036)$. Et tydeligt eksempel er beskrivelsen af Aragorn på dødslejet: "... the grace of his youth, and the valour of his manhood, and the wisdom and majesty of his age were blended together ..." $(L R, 1038)$.

Endelig er også Aragorns historiske baggrund med til at etablere ham som repræsentant for førstefunktionen. Han nedstammer fra de númenóreanske konger $(L R, 215)$, en menneskeslægt, hvis syndefald bestod i en overdreven udøvelse af førstefunktionen. Gennem generationer voksede de númenóreanske kongers magtbegær og arrogance, indtil de til slut ville måle sig med guderne selv, forfaldt til afgudsdyrkelse og brød gudernes forbud (Sil, 313f; LR, 1011f).

Hvor menneskenes mytologiske fortid således udspiller sig som en tematisering af, hvordan førstefunktionen fejlede, udgør elvernes forhistorie en tematisering af andenfunktionens forgæves kamp. Noldornes mange hundrede år lange krig mod ondskaben i skikkelse af Morgoth kaldes "the Siege of Angband" (fx Sil, 137) og kulminerer, da guderne griber ind i et Ragnarok-lignende slag (Let, 147f). Som Munier påpeger, er Noldornes krigslyst, tapperhed, voldelige temperament og smedekunst med til at etablere dem som andenfunktionsvæsener (Munier 1987a, 44-49). Heri ligner de elvernes komplementære modpart, dværgene, hvis fortid også er defineret af krige ( $L R$, 1046. 1048). I lighed med elverne får dværgene meget få børn $(L R, 1053)$ og er suveræne inden for smedekunsten (Sil, 108f). I Ringens Broderskab repræsenteres elvere og dværge af Legolas og Gimli, hvis indbyrdes forhold udvikler sig fra fjendskab til våbenbroderskab og venskab, en positiv udvikling der dog forbliver inden for andenfunktionens felt. Legolas og Gimli omtales primært i forbindelse med kampsituationer (LR, 290f, 317), og de er de bærende fortællerstemmer i slaget ved Helms Kløft (LR, 520-526). De har derimod ingen forbindelse til de andre funktioner: magien, den overordnede planlægning eller temaet omkring Ringen.

Den tredje krigerfigur, Boromir, søn af Gondors regent Denethor, gennemløber i modsætning til Legolas og Gimli en negativ udvikling inden for andenfunktionen, hvis begrænsning han ikke forstår. Han er arrogant over for førstefunktionen (LR, 239f, 297, 349) og sammenligner fejlagtigt Ringen med et våben $(L R, 260 f)$. Ved at måle alting på 
andenfunktionens skala overvurderer han sine egne evner og tror, at Ringen kan gøre ham til en mægtig hærfører og siden til konge $(L R, 389)$. Hermed begår han en synd, der også i indoeuropæisk mytologi er typisk for andenfunktionen, nemlig at efterstræbe den suveræne magt, at tro sig værdig til at udfylde førstefunktionen (Munier 1987a, 49).

Boromir har dog samtidig en række positive andenfunktionskarakteristika $(L R, 269$, 404, 748), der forbinder ham mere med Rohanrytterne end med sit eget folk, menneskene fra Gondor $(L R, 425)$. Rohan er som elverne en kultur båret af sang (fx $L R, 449$. 775. 1039). De er karakteriseret ved deres kampglæde (fx $L R, 820$ ) og opfatter krigen som et mål i sig selv $(L R, 663)$. De omtales som stolte, viljefaste, oprigtige og tapre ( $L R$, $420)$ og er associeret med ungdom ( $L R, 663.1042)$; alt sammen markører for andenfunktionen. Over for Rohan står førstefunktionskulturen Gondor, der er højtudviklet, lærd og kultiveret, men samtidig også mere dekadent (fx Shippey 1992, 113f). Gondor repræsenterer kulturhistorien og visdommen $(L R, 663)$ og er sæde for magtens centrum, Minas Tirith. En parallelitet gør sig samtidig gældende i Rohans og Gondors kongehuse, der hver især på et nyt niveau danner en trefunktionel struktur.

Historien om andenfunktionens hybris og nemesis i skikkelse af Boromirs fald efterfølges af en ny kriger, Éomer, der repræsenterer andenfunktionens positive udfoldelse. I modsætning til Boromir er Éomer en kriger i sin rette kontekst: blandt sine mænd, i en krigerkultur, i krigen ( $\mathrm{fx} L R, 421 \mathrm{f}, 826$ ). Hans dyder er den sande loyalitet og respekt for kongen $(L R, 426,862)$. Éomer har forladt kongeborgen, Meduseld, og med ham er andenfunktionen forsvundet. Våben er forbudt, og også kongen er handlingslammet og ude af stand til at træffe valg $(L R, 497 \mathrm{f})$ og dermed udøve sin førstefunktion. Kongedatteren Éowyn har en række andenfunktionskarakteristika $(L R, 512$, 848), som hun i overdreven grad udlever ved at opsøge døden i kamp (Dickerson 2003, 37f). Samtidig er hendes handlinger følelsesbårede ( $L R, 766 \mathrm{f}, 822)$ og udmunder $\mathrm{i}$ helbredelse og kærlighed (LR, 937f), hvilket placerer hende i tredjefunktionen.

Som Boromir udgør et eksempel på en overdreven andenfunktionsudøvelse, er hans far, Denethor, et eksempel på førstefunktionens hybris. Han er vis, lærd og fremsynet ("far-sighted", LR, 1030), og har stor viljestyrke ( $L R, 742 \mathrm{f})$. Dog kender han ikke sin egen magts og kongeligheds begrænsning, da han ser i palantíren, en magisk seersten fra Númenor, og opnår en viden, han ikke er i stand til at forvalte $(L R, 1031)$. Boromirs bror Faramir bærer som Éowyn både træk fra sin egen kultur og fra tredjefunktionen. Fra Gandalf har han en stor viden $(L R, 1031)$; han interesserer sig for historien $(L R$, 941) og er modtagelig for drømmesyn $(L R, 239)$. Samtidig er han associeret med det emotionelle ( $L R, 791 \mathrm{f}, 938)$; mødet med ham foregår i det frugtbare Ithillien, Gondors Have ( $L R, 635 \mathrm{f})$, og han viser modstandsdygtighed mod Ringen ( $L R, 665 \mathrm{f})$, hvilket identificerer ham som tredjefunktionsfigur.

Hobbitternes relation til tredjefunktionen kommer dels til udtryk i deres kultur, der dyrker gavegivning, slægtsforskning i store familier, god mad og fred og ro $(L R, 1 \mathrm{f}, 7)$. Hobbitternes land, Herredet, er et frugtbart landbrugsland uden konge og stort set uden ordensmagt $(L R, 9 \mathrm{f})$. Der har aldrig været intern krig mellem hobbitterne og i mange år heller ikke mod en ydre fjende $(L R, 5)$. Dertil kommer hobbitternes snusfornuft og 
modvilje mod alt, hvad der er magisk og overnaturligt (fx $L R, 1,30,43 f$ ), hvilket til sammen danner billedet af en kultur med mange tredjefunktionselementer og et fuldstændigt fravær af både første- og andenfunktionen.

Blandt hobbitterne i Ringens Broderskab udgør især deres stærke indbyrdes relationer og betydningen af det nære venskab ( $\mathrm{fx} L R, 269,718,750 \mathrm{f}$ ) væsentlige tredjefunktionselementer. Dertil kommer, at selve hobbitternes antal - et udtryk for tredjefunktionens mangfoldighed og overflod - ved flere lejligheder viser sig at være et aktiv i kampen mod det onde $(L R, 434,581)$. Endelig er ikke mindst hobbitternes modstandsdygtighed over for Ringen et tydeligt tredjefunktionstegn.

Ringen er relateret til og frister med magt og storhed (fx Dickerson 2003, 95f), som hobbitterne generelt er uinteresserede i $(L R, 880 \mathrm{f})$. Samtidig opererer hobbitterne suverænt over for selve fristelsen fra Ringen, fordi begær, ønske og behovsopfyldelse netop er deres felt, og de forstår derfor dels i højere grad end andre at modstå begæret; men vigtigere endnu formår de at skelne deres eget, sande begær fra det falske begær, der kommer fra Ringen ( $L R, 194,689 f)$. I sin ydre fremtoning er Ringen en tredjefunktionsgenstand: den er smuk, ren, kostbar, perfekt og af guld $(L R, 59)$. Imidlertid bringer denne skat ingen tilfredshed at eje, men derimod uro $(L R, 34)$. Ejerskabet kan ikke deles ( $L R, 890 \mathrm{f})$, og den tilsyneladende udødelighed, Ringen giver, er i virkeligheden uden liv, for bæreren vokser ikke, men fortæres af Ringen $(L R, 46)$. Mod denne perversion af en tredjefunktionsgenstand er hobbitternes materialitet $(L R, 216)$, generøsitet $(L R, 34,60,356)$ og ikke mindst deres naturlige begær efter mad uvurderlige kvaliteter.

Hvordan det falske begær efter Ringen modsvares af det sande begær efter maden, kommer tydeligt til udtryk på Sams og Frodos rejse mod Mordor, der er karakteriseret af en kamp mod sulten, mod Ringen og med og mod Gollum: konflikter, der alle tre udspiller sig omkring fortæring. Hvor Sam er den tykke og sultne hobbit, der bekymrer sig om maden (fx $L R, 590,607)$, er Gollum anorektisk $(L R, 608)$, potentielt kannibalistisk $(L R, 614,619)$ og har i det hele taget sære, kulinariske præferencer $(L R, 612$, 639), der udelukker ham fra Sams og Frodos måltidsfællesskab. Frodos tilstand midt imellem den sunde hobbitnatur og påvirkningen fra Ringen er i den alimentære kode udtrykt ved en stigende indifferens over for spisning, efterhånden som hans naturlige, livsopbyggende sult fortrænges af det livsnedbrydende begær efter Ringen. Endelig fremstår selve opgavens fuldførelse som en serie af fortæringer. Ringen æder Frodo op indefra, Gollum æder - konkret - Frodos finger og Ringen, hvorefter både Gollum og Ringen fortæres af ilden.

\section{Trefunktionalitetens videre udfoldelse}

Forskellen på ondt og godt i $R H$ er strukturelt set den, at det gode repræsenteres af en række forskellige og autonome kulturer, mens det onde tilsyneladende repræsenteres af én udifferentieret masse, styret af én vilje. Imidlertid viser det sig, at trefunktionaliteten i $R H$ ikke blot er et definerende karakteristikum ved det gode, men at også det onde ved nærmere eftersyn fremstår trefunktionelt. Hermed bliver den trefunktionelle struktur 
definerende ikke blot for den gode side i kampen mellem godt og ondt, men også for, hvordan selve fortællingen om konfrontationen mellem godt og ondt udfolder sig.

Hvor hobbitternes kamp mod Ringen repræsenterer en konfrontation med ondskaben, der foregår inden for tredjefunktionen, er Ringkrigen den konfrontation med ondskaben, som foregår inden for andenfunktionen. Orkerne, Saurons krigsmaskine, er ikke blot dem, man fører krig mod; de er også en gruppe, der i sig selv er karakteriseret ved stridbarhed og intern krig, en svaghed, der flere gange kommer heltene til gode ( $L R$, 435f, 882f, 910). De er ren destruktion, en ukontrolleret og overdreven andenfunktion, men renset for andenfunktionens dyder såsom mod og ære. Orkerne fremstår således som den symmetriske modpol til de mest moralske repræsentanter for andenfunktionen, nemlig elverne. Dette indtryk forstærkes af historien om, hvordan orkerne oprindeligt blev fremavlet af tilfangetagne og torterede elvere (Sil, 58). Ifølge fortællingens logik står hæren af ubetinget onde orker altså over for hæren af de ubetinget gode elvere, mens menneskene findes på begge sider ( $\mathrm{fx} L R, 171)$.

Orkerne er ude af stand til at agere uden Saurons vilje $(L R, 928)$, hvorimod de mennesker, der var på henholdsvis Saurons og Sarumans side, stadig kæmper videre, da Sauron er væk, indtil Aragorn løser konflikten diplomatisk ved en fredsslutning ( $L R$, 947). Orkerne repræsenterer den metafysiske ondskab, der konfronteres gennem krig, mens menneskene repræsenterer den ondskab, der konfronteres politisk. Der er derfor også en parallel i, at ikke blot orkerne, men også deres absolutte modsætning, elverne, forsvinder fra Midgård, da Ringkrigen er slut. Freden og den fjerde tidsalder tilhører menneskene.

Inden for førstefunktionen manifesterer Saurons ondskab sig som Øjet, der er symbol på en overvældende magt og vilje. ${ }^{9}$ Øjet eller Saurons vilje konfronteres af førstefunktionsfigurerne gennem palantírerne, der blev bragt til Midgård med de første konger, og som gav disse evnen til at se langt både i rum og i tid (Sil, 351f). Brugen af dem kræver mental styrke og er forbeholdt konger og regenter (UT, 403f), og de fungerer således symbolsk som genstande, der forener synet, kongeligheden, magten og viljen, og som derfor er medium for konfrontation med det onde på disse (førstefunktions-) områder.

Den nære sammenhæng mellem den rette udøvelse af førstefunktionen og evnen til at konfrontere Sauron gennem synet kommer til udtryk hos de personer, der forsøger at bruge palantírerne. Saruman og Denethor misbruger dem gennem deres overmod og falder under Saurons vilje. Da Saruman mister magten, mister han også palantíren ( $L R$, 569), og da Denethor mister forstanden og brænder op, bliver palantíren samtidig ødelagt $(L R, 836)$. Kun Aragorn formår at vise sig for Sauron i palantíren og gennem en viljeskamp at se uden selv at blive gennemskuet $(L R, 763)$.

Konfrontationen med Saurons ondskab udspiller sig således inden for alle tre funktioner med forskellige manifestationer af Sauron på den ene side og forskellige helte som aktører på den anden. Den trefunktionelle struktur bliver dermed også

\footnotetext{
${ }^{9}$ Som Chance bemærker, kan Tolkiens symbol her betragtes som en illustration af Foucaults beskrivelse af sammenhængen mellem magt og overvågning (Chance 2001, 21).
} 
definerende for det narrative forløb, der efter broderskabets opsplitning deler sig i mange handlingstråde. Frodo og Sam følger den del af handlingen, der drejer sig om Ringen, Gollum, rejsen gennem Ithilien og kampen mod Shelob, et udpræget tredjefunktionsmonster (LR, 707f). Merry og Pippin følger først den handlingstråd, der handler om Fangornskoven og vækkelsen af enterne, de trælignende hyrder for skoven. Siden er disse to de afgørende aktører i historien om, hvordan henholdsvis Faramir og Éowyn bliver reddet, og Merry er mediator for, at de mødes $(L R, 940)$, helbredes og sammen realiserer deres tredjefunktionpotentiale. De dele af handlingen, hvori hobbitterne er aktører, udspiller sig således primært omkring tredjefunktionstemaer. Legolas, Gimli og Aragorn rejser derimod gennem Rohan og følger krigstemaet til slaget ved Helms Kløft, Pelennorsletten og Dagorlad. Aragorn har derudover sit eget tema med palantíren, rejsen ad De Dødes Stier og endelig ankomsten og helbredelserne i Minas Tirith. Gandalf følger sin egen handlingstråd, der kredser om de to konger og forsøget på at rådgive og vejlede dem samt at varetage styringen af Minas Tirith, da Denethors galskab og handlingslammelse bliver tydelig $(L R, 806)$.

Overordnet kan man betragte det således, at Ringen på første del af sin rejse beskyttes af førstefunktionen i kraft af Aragorns og Gandalfs evner. Først i Moria kommer den væbnede konflikt ind i historien; men kamptemaet spalter sig snart igen ud fra Ringens rejse, der efter broderskabets opsplitning udelukkende bæres frem af evner relateret til tredjefunktionen. Hermed opstår et funktionsdefineret skel mellem den handling, der udspiller sig øst for floden Anduin, relateret til tredjefunktionen, og den handling, der udspiller sig vest for Anduin, relateret til første- og andenfunktionen. Skellet har samme grundstruktur, som Dumézil påviser i sine undersøgelser af funktionskrigen, nemlig at trefunktionaliteten synes overlagt med en binær struktur, hvor første- og andenfunktionen står over for tredjefunktionen. ${ }^{10}$ Funktionskrigens skel udtrykker sig også i modsætningen mellem Herredet og hobbitterne på den ene side og 'Den store Verden' bestående af elvere, dværge og mennesker på den anden. Endelig kommer skellet mellem første- og andenfunktionen på den ene side og tredjefunktionen på den anden side til udtryk i mindre skala i Rohans og Gondors kongehuse, hvor både Éowyn og Faramir er udstødte og oversete (Bradley 1969, 113f).

Et gentagent tema i $R H$ er, at isolation er en last, mens kommunikation er en dyd ( $\mathrm{fx}$ $L R, 146 f, 238,339)$. Det onde er det, der adskiller og skaber fjendskab, mens det gode er det, der samler og skaber alliancer. Imidlertid har også selve konfrontationen mellem det gode og det onde en kontaktformidlende rolle, og $R H$ er således - også - fortællingen om, hvordan Ringkrigen formidler den store syntese mellem lande, folk og ikke mindst funktioner. Da Aragorn kommer til Gondor og genetablerer kongedømmet, blomstrer landet op og de diplomatiske alliancer fornys, mens han med tiden skaber et storrige $(L R, 949)$; en syntese forårsaget af førstefunktionen. Krigen, andenfunktionen, genskaber alliancen mellem Rohan og Gondor, og hobbitterne bringer tredjefunktionen

\footnotetext{
${ }^{10}$ Dumézil behandler bl.a. dette tema i Mythe et Epopée I, (Dumézil 1968, 285-303).
} 
ud i Den store Verden, dels ved at indskrive sig i den større verdenshistorie $(L R, 932)$ og dels ved at formidle forbindelsen mellem Éowyn og Faramir.

Et resultat af kampen mod det onde er således en verden, hvor de tre funktioner er blevet integreret. I modsætning til tidligere $(L R, 242)$ har Herredet nu oplevet krigens nødvendighed og er blevet en del af Det forenede Kongerige $(L R, 13)$. Og både Merry, Pippin og Sam vedbliver hele deres liv at være syntetiserende figurer, der bevarer kontakten til Den store Verden ( $L R, 1071 \mathrm{f})$. Hovedpersonerne i Ringens Broderskab fungerer således som forbindelsesled mellem kulturer og funktioner; men som Kocher rigtigt bemærker, er dette ikke ensbetydende med, at ordenens genoprettelse består i at ophæve den grundliggende struktur (Kocher 2002, 127f). Paradoksalt nok går funktionssyntesen og styrkelsen af den trefunktionelle struktur hånd i hånd. Aragorn indstifter den lov, at ingen mennesker må komme i Herredet $(L R, 1071)$. Mens han selv bliver konge i førstefunktionslandet Gondor, bliver Éomer konge i andenfunktionslandet Rohan, og de to tredjefunktionsfigurer, Faramir og Éowyn, bosætter sig i tredjefunktionslandet Ithilien, et geografisk valg som samtidig for dem begge er et funktionsvalg ( $L R, 943 \mathrm{f})$ Handlingen i $R H$ foretager således en 'oprydning' i funktionerne, der tydeliggør, hvem der hører til hvor, og samtidig skaber samtidig en øget kontakt mellem dem.

Som jeg har redegjort for i det foregående, udfolder funktionerne sig i $R H$ 's handling gennem de tre temaer: kongen, krigen og Ringen. Imidlertid er der mange eksempler på, at disse tre konfrontationer ikke er lige vigtige, men at de egenskaber, der er knyttet til tredjefunktionen, er særligt afgørende ( $L R, 262,268 f, 860)$. Det er således indlysende, som også Munier redegør for (fx Munier 1987a, 80, 113), at tredjefunktionen har tematisk og moralsk forrang for de to andre funktioner. Den konfrontation med ondskaben, der foregår inden for tredjefunktionen, er den væsentligste, og tredjefunktionens dyder har højere status end de dyder, der knytter sig til de to andre funktioner. Med prioriteringen af tredjefunktionen i $R H$ danner der sig en trefunktionalitet i afslutningerne på Midgårds tre tidsaldre (Munier 1987a, 121). Første tidsalder, der rummer historien om en forgæves krig, slutter med et kosmisk slag; anden tidsalder, der rummer historien om et kongedynasti i forfald, slutter med menneskekongernes konfrontation med Sauron og et brud på den guddommeligt indstiftede orden - og tredje tidsalder, der rummer historien om Ringen, slutter med hobbitternes rejse til Mordor. Igen adskiller tredjefunktionskonfrontationen sig fra de to foregående ved at være den eneste, der lykkes.

\section{Perspektivering}

I det foregående har jeg redegjort for, hvordan trefunktionaliteten i $R H$ adskiller sig fra trefunktionaliteten $\mathrm{i}$ indoeuropæisk mytologi ved både at optræde som en struktur blandt de gode og blandt de onde. En anden markant forskel er, at det indbyrdes forhold mellem funktionerne er vendt om, idet tredjefunktionen hos Tolkien har forrang for de to andre, mens den i det indoeuropæiske materiale betragtes som den mest inferiøre (Dumézil 1970, 84f). 
Som Munier endvidere bemærker, er både Gandalf(Munier 1987a, 105), Faramir og Sam (s. 98, 134f) eksempler på, at førstefunktionen hos Tolkien har optaget elementer fra tredjefunktionen, mens tredjefunktionen har optaget elementer fra førstefunktionen, og at der derfor er en flydende grænse mellem første- og tredjefunktionskarakteristika. Da både Tolkien selv og andre fremhæver Sam som fortællingens vigtigste helt (Let, 161; Caldecott 1999; Munier 1987a, 131f) fremstår endvidere det generelle indtryk, at prøvelser, dyder og personer, der optræder inden for tredjefunktionen, har narrativ og moralsk forrang frem for dem, der er knyttet til de to andre funktioner. Munier ser dette som et udtryk for Tolkiens kristne overbevisning, der nødvendigvis må afvise volds- og magtudøvelse, men som værdsætter skønheden (Munier 1987a, 99f). Det er dog ikke skønheden, der karakteriserer tredjefunktionen i $R H$, men derimod hobbitternes dyder såsom kærlighed og venskab, ydmyghed, fredsommelighed, opofrelse, det jævne, almindelige liv og evnen til at skelne det sunde fra det usunde begær. Disse egenskaber har et tydeligt kristent præg; men det betyder ikke, som Munier antyder, at første- og andenfunktionen er af det onde. Visdom, krig og i begrænset omfang magtudøvelse har også sin berettigelse i $R H$, ligesom tredjefunktionen kan perverteres, sådan som Gollum er eksempel på. Tolkien følger den klassiske, indoeuropæiske mytologi i at insistere på helhedens nødvendighed; det kristne præg ligger udelukkende i, at det interne værdihierarki mellem funktionerne er vendt om. Dette kan også helt generelt ses som et udtryk for det kristne tema, som er tydeligt i $R H$, at "de sidste skal blive de første og de første de sidste" (Caldecott 1999, 115).

Endelig kan tredjefunktionens forrang hos Tolkien ses som et udtryk for, at de moderne værdier overtrumfer de arkaiske. Shippey betragter Hobbitten som Tolkiens forsøg på at åbne folkeeventyrets og den arkaisk-heroiske verden for et moderne publikum. Mediatoren for dette er Bilbo, der selv er en anakronisme i en arkaisk verden, og Shippey påpeger, hvordan hobbitterne også i $R H$ optræder som anakronismer (Shippey 2001, 6f). Set i dette lys er skellet mellem på den ene side første- og andenfunktionen og på den anden side tredjefunktionen et skel mellem værdierne i henholdsvis den arkaisk-heroiske og den moderne verden. Igen er det værd at bemærke, at Tolkiens pointe er, at der er brug for begge dele - det er selve mediationens formål at argumentere for dette - men at det i sidste ende ikke er den ydre, men den indre kamp og hverdagens heltedåd: udholdenheden, fællesskabet og den daglige kamp for overlevelse, der er det afgørende.

Man kan nu overveje, hvilke videre konklusioner eksistensen af den trefunktionelle struktur i $R H$ kan give anledning til. Det er næppe sandsynligt, at Tolkien bevidst har indarbejdet den. Dels er $R H$ og teorien om den trefunktionelle struktur blevet til omtrent samtidig, og Tolkien kan næppe have kendt til Dumézils arbejde. Som Chausse bemærker, er det heller ikke sandsynligt, at han selv har gjort de samme opdagelser parallelt med Dumézil (Chausse 2003, 5), og i det hele taget får man det indtryk, at han var meget lidt bevidst om, hvordan hans egen fortælling ville udforme sig (Bratman 2000, 14). En nærlæsning af Tolkiens tidlige udkast til $R H$ afslører en række eksempler på, 
hvordan den trefunktionelle struktur træder tydeligere og tydeligere frem med revisionerne (fx Let, 104, 216, RS, 261).

Studiet af revisionerne giver det samlede indtryk, at trefunktionaliteten hverken er opstået tilfældigt eller konstrueret bevidst. Dette understøtter den antagelse, at Tolkien ubevidst har reproduceret strukturen fra den indoeuropæiske, mytologiske tradition, han var så velbevandret i (Chausse 2003, 5). En mulighed er, at den bevidste brug af temaerne herfra har ført en ubevidst strukturreproduktion med sig, eller at Tolkiens forestilling om, hvordan den gode fortælling er bygget op, var dybt præget af hans egen mytologiske kulturarv. I den forbindelse er det interessant at bemærke, at det finske heltedigt, Kalevalaen, som Tolkien var stærkt optaget af, og hvis univers også var en væsentlig inspirationskilde særligt til Silmarillion, ikke indeholder spor af trefunktionalitet (Dumézil 1968, 632).

Endelig foreligger den mulighed, at trefunktionaliteten udgør en universel mytestruktur, som Tolkien ubevidst har reproduceret. Munier mener, at dette er tilfældet, og foreslår, at Tolkien og Dumézil har ladet sig lede af en parallel intuition, som LéviStrauss udtrykker det: at myten tænker i menneskene uden deres vidende (Munier 1987b, 212). Den spontane dannelse af den trefunktionelle struktur er imidlertid et problem for Dumézils grundtanke om, at trefunktionaliteten er noget, der er særligt knyttet til det indoeuropæiske kulturområde. Hvis den trefunktionelle struktur kan opstå spontant, er dens forekomst i indoeuropæisk påvirkede kulturer ikke tegn på en traditionsmæssig kontinuitet, men derimod en tilfældighed (Jensen \& Schjødt 1994, 189f). Spørgsmålet om trefunktionalitetens mulige universalitet er således et valg for eller imod en generel overbevisning om anvendeligheden af Dumézils teori, hvilket er en ganske anden og mere vidtrækkende diskussion.

Eksistensen af den trefunktionelle struktur er imidlertid også interessant for studiet af Tolkien. Som Shippey påpeger, er den overordentligt velstrukturerede symmetri i $R H$ en væsentlig del af årsagen til bogens succes (Shippey 2001, 51f), og med en trefunktionel analyse afsløres nye lag af symmetrier, som bidrager til kortlægningen af, hvad $R H$ også indeholder. Hermed bliver Dumézils teori et interessant redskab til udforskning af, hvilke temaer og værdier, der gør sig gældende i fortællingen, og den peger dermed ud over en rent strukturel analyse. Tilstedeværelsen af den trefunktionelle struktur kan også betragtes som en indikation af, at Tolkiens ambition om at skabe en asterisk-mytologi for England (Shippey 2001, xv) er lykkedes, i hvert fald hvad angår den overordnede struktur. Under alle omstændigheder er det givet, at hvis Dumézils teori holder stik, og hvis Tolkien med sit værk vitterlig havde rekonstrueret et mytologisk univers, som det fandtes engang, så ville dette univers med stor sandsynlighed udvise en trefunktionel struktur.

\section{Konklusion}

Ud fra den grundlæggende fordeling af funktionerne, som kommer til udtryk i Ringens Broderskab, har jeg vist, hvordan trefunktionaliteten manifesterer sig på flere forskellige felter i RH. Personernes kulturelle baggrund, Midgårds geografi, forhistorien og måden, 
hvorpå ondskaben konfronteres i $R H$ er tydeligt trefunktionel. Skematisk kan strukturen udtrykkes således:

\begin{tabular}{|l|l|l|l|}
\hline & Førstefunktionen & Andenfunktionen & Tredjefunktionen \\
\hline Helte & Gandalf, Aragorn & $\begin{array}{l}\text { Legolas, Gimli, } \\
\text { Boromir, Éomer }\end{array}$ & $\begin{array}{l}\text { Frodo, Sam, } \\
\text { Merry, Pippin } \\
\text { (Éowyn, Faramir) }\end{array}$ \\
\hline Geografi & Gondor & Rohan & Herredet, Ithilien \\
\hline Forhistorie & $\begin{array}{l}\text { De númenóreanske } \\
\text { konger (2. Alder) }\end{array}$ & $\begin{array}{l}\text { Elvernes krig mod } \\
\text { Morgoth (1. Alder) }\end{array}$ & $\begin{array}{l}\text { Kamp mod } \\
\text { Ringen } \\
\text { (3. Alder) }\end{array}$ \\
\hline $\begin{array}{l}\text { Falsk / overdreven } \\
\text { funktionsudfoldelse }\end{array}$ & Saruman, Denethor & Boromir & Gollum \\
\hline $\begin{array}{l}\text { Manifestation af } \\
\text { Saurons ondskab }\end{array}$ & Øjet & Orkerne & Ringen \\
\hline $\begin{array}{l}\text { Konfrontationen sker } \\
\text { gennem }\end{array}$ & $\begin{array}{l}\text { Palantírerne, synet, } \\
\text { viljen }\end{array}$ & Krigen & $\begin{array}{l}\text { Udholdenhed, } \\
\text { sammenhold, } \\
\text { begær }\end{array}$ \\
\hline
\end{tabular}

Trefunktionaliteten følger endvidere de dele af handlingen, der er knyttet til disse personer og steder og de tre grundtemaer: kongen, krigen og Ringen. Hermed adskiller den sig fra den indoeuropæiske trefunktionalitet ved ikke blot at strukturere den gode side, men både ondt og godt. En anden væsentlig forskel er Tolkiens omprioritering af funktionernes rangorden, idet tredjefunktionen i $R H$ rangerer højere end de to andre. Udover at belyse tematik og symmetrier hos Tolkien kan forekomsten af den trefunktionelle struktur i $R H$ give anledning til overvejelser over relevansen af Dúmezils teori. Jeg har med denne artikel påpeget, hvordan trefunktionaliteten også optræder i et stykke moderne indoeuropæisk mytologi, hvilket jeg betragter som udtryk for, at den trefunktionelle struktur - i hvert fald i en indoeuropæisk kontekst og muligvis universelt - kan betragtes som en naturlig form; den gode fortællings gyldne snit.

\section{Litteratur}

Alibert, LAURENT

2002 Imaginaire médiéval et mythologique dans l'oevre de Tolkien, I + II http://www.jrrvf.com/essais/imaginaire/partie1.html (set 4.9.2005).

BRADLEY, MARION ZIMMER

1969 "Men, Halflings and Hero Worship", in: Neil D. Isaacs \& Rose A. Zimbardo, eds., Tolkien and the Critics. Essays on J.R.R. Tolkien's The Lord of the Rings, University of Notre Dame Press, London, 109-27.

BRATMAN, DAVID

2000 "Top Ten Rejected Plot Twists from The Lord of the Rings: A Textual Excursion into the 'History of The Lord of the Rings"', Mythlore 86, 13-38. 
BURNS, MARJORIE

2000 "Gandalf and Odin", in: Verlyn Flieger \& Carl F. Hostetter, eds., Tolkien's legendaryum: essays on The history of Middle-earth, Greenwood Press, Westport, Connecticut, 219-31.

CALDECOTT, STRATFORD

1999 "Over the Chasm of Fire: Christian Heroism in The Silmarillion and The Lord of the Rings", in: Joseph Pearce, ed., Tolkien. A Celebration. Collected Writings on a Literary Legacy, Ignatius Press, San Fransisco, Californien.

CHANCE, JANE

2001 The Lord of the Rings. The Mythology of Power, The University Press of Kentucky, Lexington, Kentucky.

CHANCE Nitzsche, JANE

1979 Tolkien's Art 'A Mythology for England', The Macmillan Press Ltd., London.

CHAusse, JEAN

2003 "Heurs et malheurs de Túrin”, http://www.jrrvf.com/essais/dumezil.html (set 4.9.2005).

DiCKERSON, MATTHEW

2003 Following Gandalf. Epic Battles and Moral Victory in The Lord of the Rings, Brazos Press, Baker Book House Company, Michigan.

DUMÉZIL, GEORGES

1956 Aspects de la fonction guerrière chez les Indo-Européens, Presses Universitaires de France, Paris.

1958 L'ideologie tripartie des Indo-Européens, Latomus Revue d'Études Latines, Bruxelles.

1968 Mythe et Épopée I, L’idéologie des trois fonctions dans les épopées des peuples indoeuropéens, Éditions Gallimard, Paris.

1970 Du mythe au roman, Presses Universitaires de France, Paris.

1982 Mythe et Épopée II, Types épiques indo-européens: un héros, un sorcier, un roi, Gallimard, 3. édition.

1985 Heur et malheur du guerrier.

Gilhus, InGVILD \& LisBeth MiKAELSSON

1998 Kulturens Refortrylling. Nyreligiøsitet i moderne samfunn, Universitetsforlaget, Oslo.

HJARVARD, STIG

2005 "Medialisering af religiøse forestillinger”, in: Morten Thomsen Højsgaard \& Hans Raun Iversen, eds., Gudstro i Danmark, Forlaget Anis, København (under udgivelse).

Jensen, Hans JørGen Lundager \& Jens Peter SCHJøDT

1994 Suverceniteten, kampen og frugtbarheden. Georges Dumézil og den indo-europæiske ideologi, Aarhus Universitetsforlag, Århus.

KINCH, NANNA

2005 Kongen, Krigen og Ringen. En littercer undersøgelse af J.R.R. Tolkiens Ringenes Herre set $i$ lyset af Georges Dumézils teori om den trefunktionelle struktur i indoeuropæisk mytologi, upubliceret speciale, Aarhus Universitet, Afdeling for Religionsvidenskab.

KOCHER, PAUL

2002 Master of Middle-earth. The Achievement of J.R.R. Tolkien, Pimlico, London.

MIESEL, SANDRA

1973 Myth, Symbol and Religion in The Lord of the Rings, T.K. Graphics, Baltimore.

2005 Life-Giving Ladies, forventes publiceret i Touchstone Magazine 2005.

MUNIER, FRÉDÉRIQUE

1987a Les Réminiscences de l'Idéologie Trifonctionelle Indo-Européenne dans l'Euvre Epique de J.R.R. Tolkien, upubliceret. 
1987b "Une Interprétation trifonctionelle d'un poème de J.R.R. Tolkien", Études IndoEuropéennes 21-24, 191-212.

SHIPPEY, TOM A.

1992 The Road to MiddleEarth, HarperCollins, London.

2001 J.R.R. Tolkien. Author of the Century, HarperCollins, London.

TJALVE, LARS

1972 "Mørkets natsorte fyrste og den hvide troldmand", Fønix, Vol. 3, 177-99.

TOLKIEN, J.R.R.

1988 The Return of the Shadow. The History of Middle-earth. Volume 6, Tolkien, ed., Unwin Hyman Ltd., London $=R S$.

1989 The Silmarillion, Christopher Tolkien, ed., Unwin Hyman Limited, London = Sil.

1990 Unfinished Tales of Númenór and Middle-earth, Christopher Tolkien, ed., Unwin Hyman Limited, London $=U T$.

2000 The Letters of J.R.R. Tolkien, Humphrey Carpenter, ed. with the assistance of Christopher Tolkien, Houghton Mifflin Company, New York = Let.

2001 The Lord of the Rings I-III: The Fellowship of the Ring, The Two Towers, The Return of the King $(R K)$, HarperCollins, London $=L R$.

YANDELL, STEPHEN

1995 “'A Pattern Which Our Nature Cries Out For': The Medieval Tradition of the Ordered Four in the Fiction of J.R.R. Tolkien", in: Patricia Reynolds \& Glen H. Goodknight, eds., Proceedings of the J.R.R. Tolkien Centenary Conference Keble College, Oxford, 1992, The Mythopoeic Press, Altadena, California, 375-92.

Nanna Kinch

Cand.mag., fagredaktør på www.religion.dk

Åbyvej 65

8230 Åbyhøj 